bling scalding of the skin. Br J Dermatol. 1956;68:355-61.

3) 饭島正文. Stevens-Johnson 症候群（SJS）, 中毒性表皮壊 死症 (TEN), 王置邦彦, 他編. 最新皮膚科学大系, 第 5 巻, 東京：中山書店；2004. P36-55.

4) 飯島正文. SJS 進展型TENの早期診断と皮膚科専門医の役 割. 日皮会誌. 1999;109:1868-70。

5) 飯島正文. TENの病態と治療 - SJS進展型TEN (TEN with spots）の臨床的重要性一. アレルギー科. 2001;11:89-94.

6) Stevens AM, Johnson FC. A new eruptive fever associated with stomatitis and ophthalmia: Report of two cases in children. Am J Dis Child. 1922;24:526-33.

7) Bastuji-Garin S, Rzany B, Stern RS, et al. Clinical classification of cases of toxic epidermal necrolysis, StevensJohnson syndrome, and erythema multiforme. Arch Dermatol. 1993;129:92-6.

8) 平成 16 年度厚生労働科学研究, 難治性疾患克服研究事業, 難治性皮膚疾患（重症多形滲出性紅斑（急性期）を含む) の
画期的治療法に関する研究 (主任研究者: 橋本公二), 報告 書 (案)

9) Roujeau J-C, Chosidow O, Saiag P, Guillaume J-C. Toxic epidermal necrolysis (Lyell syndrome). J Am Acad Dermatol. 1990;23:1039-58.

10) Halebian PH, Madden MR, Finklestein JL, et al. Improved Burn Center survival of patients with toxic epidermal necrolysis managed without corticosteroids. Ann Surg. 1986;204:503-12.

11) Viard I, Wehrli P, Bullani R, et al. Inhibition of toxic epidermal necrolysis by blockade of CD95 with human intravenous immunoglobulin. Science. 1998;282:490-3.

12) Prins C, Kerdel FA, Padilla RS, et al. Treatment of toxic epidermal necrolysis with high-dose intravenous immunoglobulins. Arch Dermatol. 2003;139:26-32.

受付日 2005 年 5 月 10 日 採択日 2005 年 5 月 16 日

\title{
たこつぼ型心筋障害：救急集中治療医への啓発
}

たこつぼ型心筋障害（たこつぼ型心筋症）は1990年 広島市民病院の佐藤ら1)により提唱された疾患概念であ り，その奇妙な名称は左室造影で心尖部を中心とする 広範囲な無収縮と心基部の過収縮により収縮末期像が あたかも“たこつぼ”に似ていたことに由来する。こ の壁運動異常は冠動脈 1 枝の支配領域からは説明でき ないほど広範囲にわたりかつ冠動脈責任病変を認めず， しかも数日で回復し始め, 数週間後には全く正常化し てしまうまことに不可解な病態である。当初は我が国 の循環器内科医がその病態に興味をもったにすぎな かったが，佐藤らの第一報から 15 年が経過した現在, 我が国のみならず海外からも多くの関連報告がなされ るようになり, その臨床像は広く世界の臨床医に認知 されつつある2) 5)。たこつぼ型心筋障害はその病態の 性質上, とりわけ救急集中治療医が接する可能性の高 い疾患であると考えられ，本稿ではこれまでに集積さ れた知見をふりかえり，たこつぼ型心筋障害に関する 理解を深めたい。

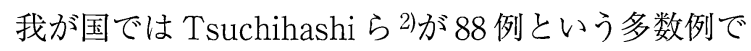
の検討を行い, 発症年齢は $67 \pm 13$ 歳，女性比は $86 \%$ と報告している。その後海外からの報告も相次ぎ, べ ルギーのDesmet ら ${ }^{3)} 13$ 例で発症年齢 $62 \pm 12$ 歳, 女 性比 $92 \%$, アメリカの Bybee ら 4) 16 例で発症年齢
$71 \pm 12$ 歳, 女性比 $100 \%$ 報告している。これら国内 外の臨床研究の結果から, たこつぼ型心筋障害は高齢 女性に好発することが明らかとなっている。

たこつぼ型心筋障害は精神的ストレスが契機となっ て発症する場合が少なくない5)。当院では肉親の死, 自 動車事故, 隣人との口論などを契機に発症した症例を 経験している。また昨年の新潟中越地震は被災者には かり知れない精神的苦痛をもたらしたが, 直後よりた こつぼ型心筋障害患者が続発しマスコミ報道で大きく とりあげられたことは記憶に新しい。発症時の主訴は 胸痛, 胸部圧迫感, 息苦しさなどの胸部症状が多く, 急 性心筋梗塞に類似する。しかし多数例を現場で経験し てみると, その自覚症状や重篤感は急性心筋梗塞に比 ベ一般に軽微であると感じられる。発症時間が曖昧で 不明である症例もあり, 自覚症状は自然消失していく ことが多い。

近年，たこつぼ型心筋障害の関連報告が精力的にな され，精神的ストレスとの関連がクローズアップされ ているが，一方で身体的ストレスが契機となって発症 する場合があることも忘れてはならない。本号で斉藤 ら6)は, 巨大声帯ポリープの嵌頓を契機に発症したたこ つほ型心筋障害の 1 例を報告している。身体的ストレ スにさらされた症例を日常的に診療している救急集中 
治療医にとって教訓的な 1 例であるが, 基礎疾患の症 状が強い場合にはたこつぼ型心筋障害そのものの症状 が隠蔽されてしまう落とし穴があることも認識してお く必要がある。さらに人工呼吸器装着例や意識障害例 では当然のことながら患者は自覚症状など訴えようが なく,基礎疾患の治療経過中にモニターの波形変化・不 整脈・血圧低下などがみられる場合にはたこつぼ型心 筋障害併発の可能性を考慮し精査をすすめていく必要 がある。以上のように, 救急集中治療, 内科, 外科, さ らには精神科といった幅広い領域に関連することも本 疾患の特徴といえよう。

胸部症状を主訴とする患者に扔いて胸部 X 線写真, 血液検査, 心電図および心エコーは確立した非侵襲的 検査である。これら検査結果をもとに診断を進めてい くわけであるが, 鑑別診断として, 急性心筋梗塞, 急 性心外膜炎, 肺塞栓症など数多くの疾患が挙げられる。 まず第一に，たこつぼ型心筋障害もまたその疾患のひ とつであることを認識しておかなければ診断に結びつ かない。上記のごとく年齢, 性別, ストレスの関与の 有無は本疾患診断の重要なポイントである。

生化学検查に扔いてクレアチンキナーゼは正常内で あるか, 軽度上昇にとどまることが多い。一方，心筋 トロポニンは心筋特異性の高い生化学マーカーである

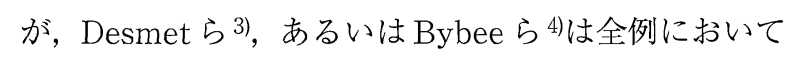
上昇していることを報告している。本疾患は機能的“心 筋障害”のみならず，軽微ながら器質的 “心筋傷害”を 伴っていることが示唆される。

心電図は急性期には ST 上昇を認め広範囲の誘導に わたることもあるが, 特に $\mathrm{V}_{3} \sim \mathrm{V}_{6}$ で大きいことが多 い。この所見は急性前壁心筋梗塞と部分的一致をみる ことから鑑別を要する。Ogura ら7は入院時心電図に おいて両者を比較し, 鏡面像としてのST 低下の欠如, 異常 $\mathrm{Q}$ 波の欠如, $\mathrm{V}_{4} \sim \mathrm{V}_{6}$ の $\mathrm{ST}$ 総和が $\mathrm{V}_{1} \sim \mathrm{V}_{3}$ のそ れよりも大であることがたこつぼ型心筋障害の診断に 有用な所見であることを報告している。また急性期に は心電図は刻々と変化するため, その一般的な経時的 変化についても認識しておく必要がある。発症早期の ST上昇は数日で基線に復する。また発症数時間後より $\mathrm{T}$ 波は陰転, QT 時間は延長し, 数日後より軽減する。 発症約 1 週間後より再び $\mathrm{T}$ 波の陰転と QT 時間の延長 がみられることが多く, その後数週間を経て心電図は 正常化する。

心エコーは心尖部から観察することにより，心尖部 を中心とする広範囲な壁運動異常を容易に検出可能で ある。これまでに僧帽弁閉鎖不全, 左室流出路狭窄, 心 尖部血栓, 心囊水貯留などのほか, 心室中隔穿孔, 左
室自由壁破裂といった致死的合併症も報告されており， 同時にこれらを検索しておくこと, 繰り返し行い壁運 動異常の回復を確認していくことが重要である。

以上の臨床的特徵および非観血的検査によりほぼ診 断可能であるが, 心電図非典型例，心エコー観察不良 例など診断に苦慮する症例が少なからず存在する。た こつぼ型心筋障害と急性心筋梗塞は予後および治療方 針が明らかに異なることから，急性期に確定診断を得 ることは重要である。近年カテーテル器具および技術 は著しく進歩し低侵襲で冠動脈造影可能となったこと から, 鑑別困難例では循環器内科医に依頼し確定診断 を得るのがよいであろう。

たこつぼ型心筋障害の病因に関しては, 多枝冠動脈 攣縮, 冠微小循環障害, カテコラミン心筋障害など諸 説入り乱れておりいまだ確定的なものはなく，それゆ えに定まった根本的治療指針はいまだ存在しない。多 くの症例では経過観察しているうちにいつのまにか自 覚症状は消失し, 心機能は正常化しているというのが 実情であり，急性期を脱すれば一般的に予後は良好で ある。しかし一過性にせ上広範囲の壁運動異常出現の ため, 急性期には肺水腫, 心原性ショック，覀性不整 脈のほか上述した器質的合併症を来しうる。各種徴候 に対しては重症度に応じて治療が必要となるが, これ らは救急集中治療医の最も得意とするところであり割 愛させていただく。現時点では刘症治療が中心となら ざるをえないが, 個々の症例の基礎疾患, 病態を把握 したうえでの慎重な対応が望まれる。

\section{栗栖 智}

広島市立広島市民病院循環器科

（解730-8518 広島県広島市中区基町 7-33）

\section{Takotsubo-like left ventricular dysfunction}

Key words: (1) Takotsubo, (2) stress, (3) ventricular function

Satoshi Kurisu

Department of Cardiology, Hiroshima City Hospital 7-33 Moto-machi, Naka-ku, Hiroshima-shi, Hiroshima 730-8518, Japan

J Jpn Soc Intensive Care Med 2005;12:186 188.

\section{文献}

1) 佐藤 光, 立石博信, 内田俊明, 他. 多枝 spasmにより特 異な左室造影「ツボ型」を示したstunned myocardium. 臨 床から見た心筋細胞障害: 虚血から心不全まで, 児玉和久, 土師一夫, 堀 正二編. 東京：科学評論社;1990.p.56-64. 
2) Tsuchihashi K, Ueshima K, Uchida T, et al. Transient left ventricular apical ballooning without coronary artery stenosis: a novel heart syndrome mimicking acute myocardial infarction. J Am Coll Cardiol. 2001;38:11-8.

3) Desmet WJ, Adriaenssens BF, Dens JA. Apical ballooning of the left ventricle: first series in white patients. Heart. 2003;89:1027-31.

4) Bybee KA, Prasad A, Barsness GW, et al. Clinical characteristics and thrombolysis in myocardial infarction frame counts in women with transient left ventricular apical ballooning syndrome. Am J Cardiol. 2004;94:343-46.
5) Wittstein I, Thiemann DR, Lima JAC, et al. Neurohumoral features of myocardial stunning due to sudden emotional stress. N Engl J Med. 2005;352:539-48.

6) 斉藤朗子, 依田建吾, 平田 学, 他.たこつぼ型心筋障害を 呈した巨大声帯ポリープの 1 症例.日集中医誌 2005;12:2138.

7) Ogura R, Hiasa Y, Takahashi Y, et al. Specific findings of the standard 12-lead ECG in patients with 'takotsubo' cardiomyopathy: comparison with the findings of acute anterior myocardial infarction. Circ J. 2003;67:687-90.

受付日 2005 年 4 月 25 日 採択日 2005 年 5 月 12 日

日集中医誌. 2005;12:188～ 190 .
今号のハイライト(6)

\section{水中毒の治療戦略}

腎の最大利尿速度は $16 \mathrm{~m} l \cdot \mathrm{min}^{-1}(1$ 日に約 $23 l)$ で あり，水分摂取がこれを越えて細胞の膨化を来した状 態を水中毒といい, その主症状は低 $\mathrm{Na}$ 血症, 低浸透圧 血症を基盤とした脑浮腫による意識障害, 痓攣発作で ある。水中毒に伴う横紋筋融解症 (rhabdomyolysis,

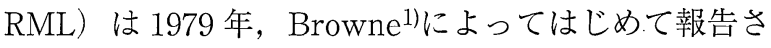
れ，我が国でも 1980 年代から報告されるようになっ た2)。この病態は精神疾患患者にしばしば認められる病 的多飲に起因することが多い。また，抗精神病薬によ る悪性症候群時の高クレアチンキナーゼ（creatine kinase, CK）血症も稀でばなかったことが精神科領域以 外で注目されなかった遠因かもしれない。我が国にお いて 1994 年以降に報告され，筆者が検索しえた RML 併発の水中毒患者 21 編 23 症例（以下，検討 23 症例） ならびに現時点における本症の問題点について言及す る。

\section{1）水中毒の発生頻度，発生機序}

本号で古川ら 引はこの病態が稀であるとしているが， はたしてそうであろうか。松田 ${ }^{2)}$ は精神病院入院患者 の10〜20\%に多飲患者を認め，4～12\%に低ナトリウ ム $(\mathrm{Na})$ 血症を，3〜4\%に水中毒が発生するとしてい る。原西ら ${ }^{4}$ は我が国における非外傷性RML 289 症例 を発生原因別に検討しているが, その中で水中毒は薬 鼡, 感染, 糖尿病性昏睡に次いで多く, 決して稀な病 態ではない。

発症機序に関しては Adler ${ }^{5}$, Curtis $^{6)}$ による 2 大仮 説が主流で多くの論文もほとんどこの考察に終始して いる。2説の詳細は, 古川ら ${ }^{3)}$ の論文に譲るが, 筆者は
Adler の提唱する「細胞外液浸透圧の変化」を支持す る。その根拠としてRMLは高 Na 血症, 糖尿病性昏睡, 低血糖でも報告されていることが挙げられる。血清浸 透圧 $=2(\mathrm{Na}+\mathrm{K})+$ 血糖值 $\left(\mathrm{mg} \cdot \mathrm{d} l^{-1}\right) / 18+$ 血清尿 素窒素 $(\mathrm{mg} \cdot \mathrm{d} l-1) / 2.8$ の簡易式で表されるように, 血漿浸透圧は血清 $\mathrm{Na}$ 以外に血糖, 血清尿素窒素にも 影響される（ただし，尿素は細胞膜を自由に通過する ため有効浸透圧としては作用しない)。Singhal ら》は 糖尿病性ケトアシドーシスの患者で, RML例（平均血 清 CK $\left.7,156 \mathrm{IU} \cdot l^{-1}\right)$ の平均血漿浸透圧が $381 \mathrm{mOsm}$. $\mathrm{kg} \cdot \mathrm{H}_{2} \mathrm{O}^{-1}$ で非 RML 例（血清 $\mathrm{CK} 61 \mathrm{IU} \cdot l^{-1}$ ）の平均 血漿浸透圧は $324 \mathrm{mOsm} \cdot \mathrm{kg} \cdot \mathrm{H}_{2} \mathrm{O}^{-1}$ であったとして いる。また，高 $\mathrm{Na}$ 血症患者においても血清 $\mathrm{Na}$ と血清 CKには正の相関があるとする報告もある8)。以上から 血清 $\mathrm{Na}$, 血糖値の急激な変化が（上昇あるいは低下ど ちらでも）血墏浸透圧に影響し，RMLを発症させるの ではないかと推察される。低K血症, 低血糖での RML 発生が少ないのは正常值からの変動幅が狭いためであ り，発生にはその他の因子も考えられる。

2) 抗利尿木儿モン不適合分泌症候群 (Syndrome of inappropriate of antidiuretic hormone, SIADH) $の$ 関与

水中毒に関しては従来より SIADH の関与を示唆す る報告が多い 2,9,1,10)。精神症状の悪化から SIADH が発 症した報告, ハロペリドールに代表される高力価抗精 神病薬の登場以降に水中毒が増加していること，最大 自由水クリアランスから理論的に計算される飲水量よ りはるかに少ない量で低 $\mathrm{Na}$ 血症を来していることな 